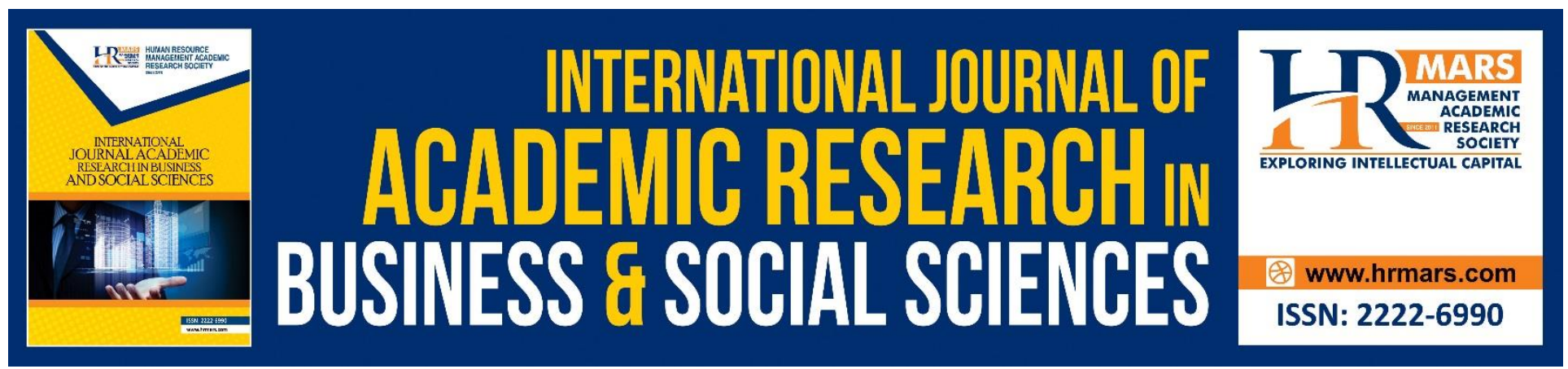

\title{
Information in Conversion Era: Impact and Influence from 4th Industrial Revolution
}

\author{
Mohd Fakrullah Mahmood, Norhayati Hussin
}

To Link this Article: http://dx.doi.org/10.6007/IJARBSS/v8-i9/4594

DOI: $\quad 10.6007 /$ IJARBSS/v8-i9/4594

Received: 19 August 2018, Revised: 26 September 2018, Accepted: 29 September 2018

Published Online: 13 October 2018

In-Text Citation: (Mahmood \& Hussin, 2018)

To Cite this Article: Mahmood, M. F., \& Hussin, N. (2018). Information in Conversion Era: Impact and Influence from 4th Industrial Revolution. International Journal of Academic Research in Business and Social Sciences, 8(9), 320-328.

\section{Copyright: (C) 2018 The Author(s)}

Published by Human Resource Management Academic Research Society (www.hrmars.com)

This article is published under the Creative Commons Attribution (CC BY 4.0) license. Anyone may reproduce, distribute, translate and create derivative works of this article (for both commercial and non-commercial purposes), subject to full attribution to the original publication and authors. The full terms of this license may be seen

at: http://creativecommons.org/licences/by/4.0/legalcode

Vol. 8, No. 9, September 2018, Pg. 320 - 328

Full Terms \& Conditions of access and use can be found at http://hrmars.com/index.php/pages/detail/publication-ethics 


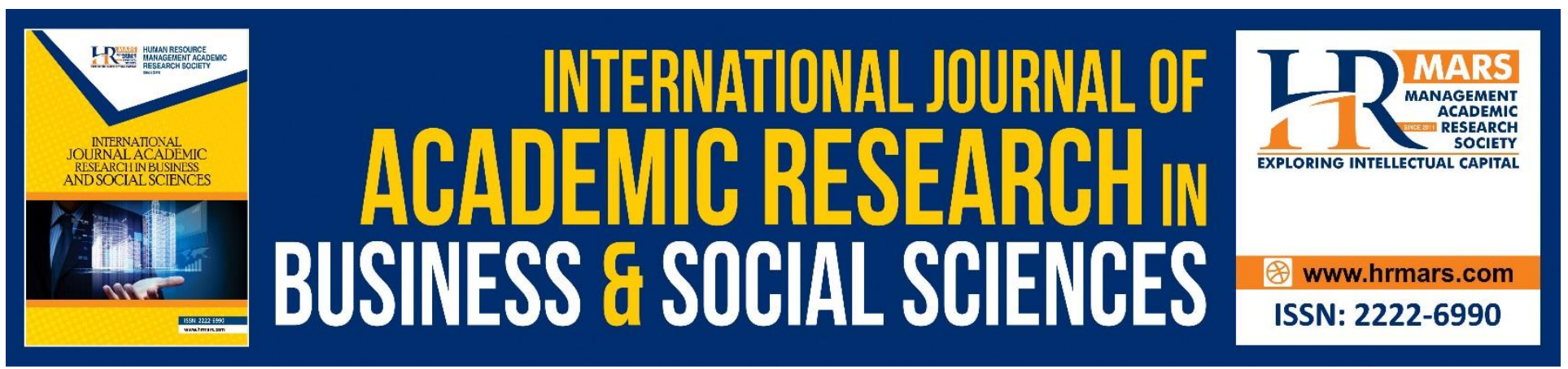

\title{
Information in Conversion Era: Impact and Influence from 4th Industrial Revolution
}

\author{
Mohd Fakrullah Mahmood, Norhayati Hussin \\ Faculty of Information Management, Universiti Teknologi MARA, UiTM Selangor,Malaysia
}

\begin{abstract}
This paper discusses the information in conversion era, the impact and influence from $4^{\text {th }}$ industrial revolution. This paper describes the phases that took place in the industrial revolution until the 4th industry. It also discussed the role of the industry revolution that generally viewed the Internet for everything in search of information. Big data which is the impact of this revolution has a lot of impact on the information gained by the user. In addition, information literacy is important and becomes the ability to access, evaluate and use information from various sources. Infopreneurship which is an entrepreneur who sells information as a product becomes a business revolution in this digital era.
\end{abstract}

Keywords: Industrial revolution 4.0, information, Information system, information management, big data, information literacy, infopreneurship

\section{Introduction}

Information is fundamental to human life. Through information, human can convey the intent, communicate well, making decisions and various aspects of life. Information is available from various sources such as print materials, audio visuals and the internet. Information is easily gained through conversations, readings, and observations. In today's technological change the information is easily accessible anywhere and anytime. Technology enables humans to interconnect without limitations and boundaries even its growing fast. With the technology now day, humans can store, arrange, process, and search for many forms of information in a short time. The phenomenon called the explosion of information make individuals to spend a lot of time just to find the information that's really relevant. This has led to the development of information industry where it is a major consumer demand that encompasses the generation of information technology savvy. Information industry has had a change because the impact of the industrial revolution. It also affects the information industry itself.

\section{Industrial Revolution, A Change}

Most of the early technological innovations stemmed from the British. This early technology evolves from time to time on demand as it develops with researchers renovating each study result to produce more efficient technology. The impact of this revolution called the industrial revolution has 
changed over time. The Industrial Revolution basically is a theory and an improvement that has deeply transformed our society and economy (Bloem, et al., 2014). The industrial revolution history is the main turning point where almost every aspect of everyday life is influenced by it. Some historians argue that the industrial revolution is due to the social and institutional change that took place with the end of Great Britain's system of feudalism after the end of the 17th century English civil war. The late 18th and early 19th centuries is the industrial revolution period when major changes in transportation, agriculture and manufacturing had a major impact on Britain's socioeconomic and cultural. Here are the reasons for the changes to the industrial revolution:

- 1st Industrial Revolution: The source of energy from water and steam technology has generated the mechanical manufacturing industry.

- 2nd Industrial Revolution: The discovery of electric energy is witnessing the extensive use of electricity in the industry.

- 3rd industrial revolution: The production of digital and industry technology led to the use of computers and the internet. Digital technology also produces new technologies to replace old energy sources.

- 4th Industrial Revolution: The 3rd industrial revolution invasion by using supercomputer technology extensively. Data and information are a major source of technological development by producing great technology.

In the middle of 2016 the industrial revolution was introduced and in 2017 it began to be said by various industries in the manufacturing, agriculture, education, science and technology sectors, management and so on. Basically the 4th industrial revolution is the digital industry and basically involves the Internet of Things (IOT) in almost all aspects of everyday life and is different from the first industrial revolution focused on the use of vapor-powered machines, second to electricity, and third to the use of information technology (IT). When the digital industry has become mature, information is available everywhere, anytime and anywhere. These are the collection of great data that available in every form of sources. The combination of large data, physical and analysis technology has changed the way of life. According to Berners-Lee and O'Hara (2013), the internet is to connect people with technology that more effective and comprehensive, such as forums, email, and this coming years, social networking sites. It also relates how we work, communicate and how we learn something. Even though this 4th industry revolution is a threat to humanity, the fact is that if it is observed it can be a turning point to current technology with proper control.

\section{Big Data Impact from the Industry Revolution}

People not realized that the industrial revolution it touches their life, moreover, when it is closely related to data revenue. Each of these individuals currently produces and deals with data. Simple daily data is a social posting such as Facebook, twitter, Instagram or communication or connection via messenger or on WhatsApp, to important data such as financial reports, stock markets or currency exchanges involving millions of currencies. Data that keep flowing all the time is described as diverse and unlimited data known as Big Data. Big Data is an explosion of information coupled with the growth of ecosystems of mobile device with fast processor capabilities, high speed Internet access and maturity of data storage technologies. Big data can be defined as a data from traditional and digital sources collection inside and outside the organization that represents a source of ongoing analysis and discovery (Smolan, Erwit, 2012). The development of the Data Raya phenomenon is also closely related to $5 \mathrm{~V}$ or in technique big data consists of 5 dimensions which is Volume, Variety, Velocity, Veracity and Value. Laney (2001) proposed that Volume, Variety, and Velocity are the three 
INTERNATIONAL JOURNAL OF ACADEMIC RESEARCH IN BUSINESS AND SOCIAL SCIENCES

Vol. 8, No. 9, Sept. 2018, E-ISSN: 2222-6990 @ 2018 HRMARS

dimensions in data management. The 3V's have developed as a common framework by others author to describe big data (Chen, Chiang, \& Storey, 2012; Kwon, Lee, \& Shin, 2014). Another 2Vs develop from the big data dimensions from current situation. It can drive to the growth of new innovations and open space to industry and government agencies to improve service quality, otherwise introduce new services that have never appeared before.

\section{Volume}

Data continues to grow every day that starts with us continuously. If before, we only use diskettes to store data, now, we need a hard drive that can store up to 1 terabyte to store our data. The daily data receipts increase of volume of data. Enhanced information technology in information industries requires data to be stored digitally. This phenomenon will caused continue of flow millions of new data, which is constantly updated, which includes the necessary data. It facilitates when it comes to sharing of information.

\section{Variety}

Information comes in various forms either by writing, numbers, pictures, audio or video. The diversity of this information is different data by application. Some data is structured, semistructured and unstructured. Cukier (2010) in his study endorses that only $5 \%$ of the data is structured from existing data. This means each of these data is not easy to group in the same database application. For example simple email message sending, every day thousands of emails are sent around the world, but each of these emails is not the same, if anything is the same, they are still different in terms of date, time, sender's address, receiver and others. Data mixture gives a difference to vector of big data.

\section{Velocity}

The vital of the industrial revolution has enhanced the computing technology in line with its frequency of practice. For modern data, it is closely related to high speed data usage requirements. The sooner we collect and use the data in life, the faster the analysis process takes place. This explains the data in the form of information initiation the decision making process by collecting tangible data and stored data.

\section{Veracity}

The base of the industry revolution 4.0 is the internet for everything. The collecting of data and information should be distinguished by authentic and complete information. It is very important when a given data provide information that we are confident to present. When a data or information is presented it leads to two purposes either accepted or rejected. It is important to analyze the data from various sources that are able to get better results. Each data included should be placed with high reliability. The data analyzed will be visually visualized to see its accuracy. General knowledge is most valuable data that be able to attract users to view or refer to our data. This is able to increase the productivity and growth of data acquisition.

\section{Value}

Each data has a value, especially the data that is informative. The valuable data that changed as information can be exploited and traded as an industry. It is important to take advantage of big data that can create business case for every effort to collect and use big data. It's easy to fall into the buzz trap by starting big data initiatives without a clear understanding of the value of the business to be taken.

Information industry uses a lot of data as a basic in business. Every business decision-making

must be driven by data. To analyze this data, researchers have developed innovative big data analytic 
tools. Analysis of big data comprises the process of checking, cleaning, changing, and data modeling with the goal of finding useful information for making a decision. Information industries are progressively gathering more data about their customers' views that has led to the propagation of sentiment analysis (Liu, 2012). Here, analytical data can be seen as a 'tool' (in the form of software) support in support of a decision through the resulting information. This is because the information acts as evidence of something involved with the decision to be made. Data analytics are also a combination of skills using information technology techniques, such as programming languages that are appropriate for data analysis and 'art' (or creativity) in understanding the resulting information; so that it can be formulated and translated into a visual form that can help the user to make a decision.

Along with the development of the information industry user must be skilled with analytic big data as the amount of data generated is on the growth of increasing digital storage technology and broader network access. The information collected when properly exploited will give user an interesting result; so long as the modern people states that the data is new oil; refers to the change from the mineral oil to the 'minerals' data. Moreover, the era of the Industrial Revolution 4.0 has benefited greatly from a combination of data analytics and artificial intelligence to provide info structures that support important decisions that will challenge the ineffective traditional business approaches and failing in the movement era.

\section{Information Literacy for Accurate Information}

Information literacy (IL) emerged along with the emergence of information technology in the early 1970s and it has been said to take up space to meet the 21st century world (Bruce, 2002). IL is fundamental to learning in a contemporary environment of constant technological change. The information environment is increasingly complex due to the rapidly expanding information and communication technology and educators recognize that learners need to engage with the information atmosphere as part of their proper learning process. IL is generally seen as very important in pursuing lifelong learning, and it is important to achieve both personal empowerment and economic development. In our information society, IL is a natural extension of the literacy concept. IL education is the catalyst necessary to transform the information society today into a

\section{The roles of Librarian and Information Professionals}

learning community tomorrow.

Librarian and information professional must view their roles to educated user about information literacy. They have an information education background that is a complete package that allows them to educate users to find information. The use of information technology itself provided such an amount of information as a reference to searching the information and it just need the proper instruction by librarian and information professional. In information skills, librarians and Information Professionals should make their users aware of the following

- identify information requirements;

- identify and locate sources of information

- detect, select information and evaluate information

- managing and organizing information

- analyze, process and comment on ethical information

- Presenting information effectively and producing new ideas 
INTERNATIONAL JOURNAL OF ACADEMIC RESEARCH IN BUSINESS AND SOCIAL SCIENCES

Vol. 8, No. 9, Sept. 2018, E-ISSN: 2222-6990 @ 2018 HRMARS

Librarians and information professional should be competent, productive, knowledgeable and profound and have high thinking skills as they have the ability to utilize new technologies and materials optimally and incorporate creativity and innovation effectively. This is important as they convey information to users for the entire life-system in information retrieval. They should also have high academic and technical qualifications, the diversity of skills and knowledge using ICT as well as positive values and work ethics.

\section{Internet of Thing (IOT)}

The development of internet technology and mobile technology has changed the way people gain contact to information, how they style technology changes and how they pick the services they use. The major effect of internet dissemination has been to connect people with pervasive technologies and ever more effective. The use of internet is limitless. They mark 'internet for everything'. Learning institutions as well, they use technology to keep pace with current educational flows. Bueno-de-la-Fuente and Hernández-Pérez (2011) state in their research, in recent years, many learning institution and universities worldwide have produced digital repositories for the learning and teaching management resources made by their academic community, or included these resources as specific collections in their institutional repositories. All of traditional library services are somehow being transformed to work in a WWW (World Wide Web) environment (Dollah \& Kadir, 2010). Internet use by user is the main focus of information retrieval. A study conducted by Kadir et al. (2011) on four research universities in Malaysia found that the majority were $27.7 \%$ of responses access internet at faculty or office, while (25.7\%) at home and the rest in dormitories (24.1\%). Internet and information literacy are very closely related. Through the use of internet the information literacy can be formed as it relates to the skills that enable individuals to identify information needs, formulate questions based on informational requirements, generate search strategies and access, evaluate, use, organize information and be able to present or convey information. Information-literate individuals can identify when information is needed and capable of effectively determining, evaluating and using information. They learn how to learn. They know how knowledge is managed and how to use information.

\section{Industrial Revolution Produces Infopreneurship}

Infopenuship have a same definition with entrepreneurship, but infopreneurship is more focus in information entrepreneur. It's actually the combination of two words which is information and entrepreneurship (Njabulo \& Gugulethu, 2015). Infopreneurship is about selling the information in many forms, formats or delivery methods. From the form of physical products that can be held such as book and video, there are also have an approach to selling information through event, speech, seminar or conferences nowadays. Coaching and consultation is available as well through face to face meeting or web conversation. Infopreneur such as journalist, reporter, librarians, and information professional and so on. Basically the information that infopreneurr selling like information, knowledge, experiences who are valuable, attractive and useful to others people.

Today information is a basic ingredient in knowledge based economy, is expensive, repacked, and dynamic and continues being reconfigured. Business now day are seeking a good information and they willing to pay for information that will bring and increased the profit margins and one step forward of their competitors. Information development also plays a role in the sale of information. Resulting from the impact of industrial revolution, various technologies are used either to access 
INTERNATIONAL JOURNAL OF ACADEMIC RESEARCH IN BUSINESS AND SOCIAL SCIENCES

Vol. 8, No. 9, Sept. 2018, E-ISSN: 2222-6990 @ 2018 HRMARS

information or create a database of information storage. For this some information professional take this advantage and have seized the opportunity by turning information provision into successful information commercial. In the world of virtual information, Information professional today are obliged to use new strategies and skills in order to survive, change and continue to compete. Some researcher find a ways to operate infopreneurship that can organized, disseminate information profitably and inforpreneurs generate. The ways are:

\section{i. Leveraged information:}

Using information technologies such as internet or database to create general market information and support data for research as well as for marketing plans creations, distribution channel, advertising program and pricing strategies.

ii. Customized information:

Information that is suitable for user needs and information manipulation into a format that is easily to understand.

iii. Facilitating access to information:

Inforpreneur needs to provided electronic access to information as a solution to reduce the gap between information produce and information consume to find the right information in a timely manner.

iv. Repacking Information:

Information need to organize into new information services and products so this repacking information is easy to located and can create a new products combining the information.

Infopreneur is a best world's business. There are a lot of potential and advantages when running into this information business. The development of world technologies and information brings infopreneur to the whole new level. Coulson-Thomas (2000), a scholar speculates that "information is available in very types that busy user struggle to keep up with the flow." In education industries the need of information are unlimited. Searching of information not just in lecturing hall but student can easy find on internet or database. So the progress of this business has a good impact to the society basically.

\section{Conclusion}

In conclusion, the industrial revolution has an impact on human life. The change from the first to fourth industry revolution is the result of data information that leads to human needs. Information technology is able to bring information to a higher level if it becomes the basis of world education. It is supported by the basis of unlimited data base if used continuously. Information literacy is crucial because people have to master the information to ensure the comfort of life. Individuals who face the information need to know to differentiate and evaluate the validity of information because information is always multiple. In addition, information is also able to create job opportunities with the resulting information organization. Although it can be sold individually, the information needs factor itself creates a large company to manage information more effectively.

\section{References}

Abdul Kadir, M. R., Wan Dollah, W. A. K., S. Mohd Sazili and S. Diljit (2011). Faktor-faktor Kesedaran Terhadap Perpustakaan Digital di Institusi-institusi Pengajian Tinggi di Malaysia. Informika: Jurnal Peradaban Informasi dan IImu, 1(1): 103-120. 
INTERNATIONAL JOURNAL OF ACADEMIC RESEARCH IN BUSINESS AND SOCIAL SCIENCES Vol. 8, No. 9, Sept. 2018, E-ISSN: 2222-6990 @ 2018 HRMARS

Berners-Lee, T. and O'Hara, K. (2013), "The read-write linked data web", Philosophical Transactions of the Royal Society, Vol. 371 No. 1987, available at: http://dx.doi.org/10.1098/rsta.2012.0513.

Bloem, J., Doorn, M., Excoffier, D., Maas, R. and van Ommeren, E. (2014), The Fourth Industrial Revolution: Things to Thighten the Link Between IT and OT, Sogeti Vint, Paris.

Bruce, C.S. (2002). Information literacy as a catalyst for educational change: a background paper. White Paper prepared for UNESCO, the U.S. National Commission on Libraries and Information Science, and the National Forum on Information Literacy, for use at the Information Literacy Meeting of Experts, Prague, The Czech Republic. Retrieved from http://www.nclis.gov/libinter/infolitconf\&meet/papers/bruce-fullpaper.pdf

Bueno de la Fuente, G. and Hernández Pérez, T. (2011). Estrategias para el éxito de los repositorios institucionales de contenido educativo en las bibliotecas digitales universitarias. BiD: textos universitaris de biblioteconomia i documentació, juny, n. 26. Retrieved from http://www.ub.edu/bid/26/bueno2.htm.

Chen, H., Chiang, R. H. L., \& Storey, V. C. (2012). Business intelligence and analytics: From big data to big impact. MIS Quarterly, 36(4), 1165-1188.

Cooney, T. M. (2012, November). Entrepreneurship skills for growth-orientated businesses. In Report for the Workshop on 'Skills Development for SMEs and Entrepreneurship (Vol. 28). Available at http://www.oecd.org/cfe/leed/Cooney entrepreneurship skills HGF.pdf.

Coulson-Thomas, C. 2001. Developing and supporting information entrepreneurs. Career Development International 6(4):231-235. Available at http://www.emeraldinsight.com/journals.htm?articleid=883269.

Cukier K. (2010). The Economist, Data, data everywhere: A special report on managing information, Retrieved from http://www.economist.com/node/15557443.

Edewor, N., \& Omosor, U. A. (2012). Reflections on Prospects of Entrepreneurial Librarianship in Nigeria. Information Impact: Journal of Information and Knowledge Management, 3(1-2). Available at https://www.ajol.info/index.php/iijikm/article/view/144604

Knilans, E. (2014). The 5V's of Big Data: Business, IBM, Technologies, Big Data and Analytics, sales.

Kwon, O., Lee, N., \& Shin, B. (2014). Data quality management, data usage experience and acquisition intention of big data analytics. International Journal of Information Management, 34(3), 387394.

Laney, D. (2001). 3-D data management: Controlling data volume, velocity and variety. Application Delivery Strategies by META Group Inc. Retrieved from http://blogs.gartner.com/douglaney/files/2012/01/ad949-3D-DataManagement-Controlling-Data-Volume-Velocity-andVariety.pdf 
Liu, B. (2012). Sentiment analysis and opinion mining. Synthesis Lectures on Human Language Technologies, 5(1), 1-167.

Njabulo B. K. \& Gugulethu S. N. (2015) The importance of Infopreneurship training for records and archives management students in zimbabwe. Journal of the South African Society of Archivists, Vol. 48, 2015, National University of Science and Technology, Zimbabwe.

Smolan, R. \& Erwit, J. (2012). The Human face of Big Data, Ed. Against all odds production, Sausalito, CA.

Wan Dollah, W. A. K., Abdul Kadir, M. R., (2010). Academic Digital Library in Malaysia: A Case Study on the Status of Digital Reference Services. Paper presented at National Seminar on Information Technology in the Library, Bayview Hotel, Penang, Malaysia. Retrieved from http://repo.uum.edu.my/559/1/SPEAKER_WAN_KADIR.pdf 